\title{
Indirect host effect on ectomycorrhizal fungi: Leaf fall and litter quality explain changes in fungal communities on the roots of co-occurring Mediterranean oaks
}

\author{
Cristina Aponte ${ }^{\mathrm{a}, *}$, Luis V. García ${ }^{\mathrm{a}}$, Teodoro Marañón ${ }^{\mathrm{a}}$, Monique Gardes ${ }^{\mathrm{b}}$ \\ ${ }^{a}$ Instituto de Recursos Naturales y Agrobiología de Sevilla (IRNASE) - CSIC, P.O. Box 1052, 41080 Sevilla, Spain \\ ${ }^{\mathrm{b}}$ UMR 5174 Evolution et Diversité Biologique, Université Toulouse III Paul Sabatier, 118 Route de Narbonne, 31062 Toulouse Cedex 4, France
}

\section{A R T I C L E I N F O}

\section{Article history:}

Received 1 October 2009

Received in revised form

26 November 2009

Accepted 21 January 2010

Available online xxx

\section{Keywords:}

Indirect host effect

Mediterranean forest

Mycorrhiza

Path analysis

Quercus suber (cork oak)

Quercus canariensis (Algerian oak)

Resupinate fungi

Tree-soil-fungi interactions

\begin{abstract}
A B S T R A C T
Host trees can modify their soil abiotic conditions through their leaf fall quality which in turn may influence the ectomycorrhizal (ECM) fungal community composition. We investigated this indirect interaction using a causal modelling approach. We identified ECM fungi on the roots of two coexisting oak species growing in two forests in southern Spain - Quercus suber (evergreen) and Quercus canariensis (winter deciduous)-using a PCR-based molecular method. We also analysed the leaf fall, litter and soil sampled beneath the tree canopies to determine the concentrations of key nutrients. The total mycorrhizal pool was comprised of 69 operational taxonomic units (OTUs). Tomentella and Russula were the most species-rich, frequent and abundant genera. ECM fungi with epigeous and resupinate fruiting bodies were found in $60 \%$ and $34 \%$ of the identified mycorrhizas, respectively. The calcium content of litter, which was significantly higher beneath the winter-deciduous oak species due to differences in leaf fall quality, was the most important variable for explaining ECM species distribution. The evaluation of alternative causal models by the d-sep method revealed that only those considering indirect leaf fallmediated host effects statistically matched the observed covariation patterns between host, environment (litter, topsoil, subsoil) and fungal community variables.
\end{abstract}

(c) 2010 Published by Elsevier Ltd.

\section{Introduction}

Mycorrhizal symbioses are essential for oak trees for acquiring nutrients under natural conditions (Smith and Read, 1997). Ectomycorrhizal (ECM) fungi supply plants with water and nutrients by increasing their foraging area and absorbing efficiency, and they provide an ample range of other beneficial effects as well, in exchange for photosynthesised products (Schutzendubel and Polle, 2002; Frey-Klett et al., 2005; Egerton-Warburton et al., 2007; Finlay, 2008). ECM communities contain a high diversity of fungal taxa (Taylor and Alexander, 2005), which are associated with a variety of functional strategies that contribute to forest ecosystem stability and functioning (Perry et al., 1989; Nara, 2006).

During the last decade, numerous studies have tried to unveil the role that natural factors, such as environmental conditions and host plant community composition, have on the assemblage of ECM communities (Conn and Dighton, 2000; Dickie and Reich, 2005; Buée et al., 2007). Soil abiotic conditions, namely, soil moisture,

\footnotetext{
* Corresponding author. Tel: +34 95 4624711; fax: +34 954624002.

E-mail address: aponte@irnase.csic.es (C. Aponte).
}

$\mathrm{pH}$ and nutrient availability, influence the performance and assemblage of fungal species (Brearley, 2006; Cavender-Bares et al., 2009). Host trees may directly affect the assemblage of their mycorrhizal community by exerting a selection for mycorrhizal species (Ishida et al., 2007; Tedersoo et al., 2008).

In a recent study Morris et al. (2008) studied the separate effects of soil conditions and host tree species on the composition of ECM communities in a California mixed-oak forest and concluded that both explained a significant proportion of the variation in ECM species distribution. These effects have usually been investigated independently despite the fact that host trees, acting as ecosystem engineers, may also indirectly shape ECM communities through their ability to modify the abiotic conditions of their environment (Jones et al., 1994; Bennett et al., 2009). The magnitude and direction of these changes are species-specific, and they can be mediated by litter quality and biomass, root exudation and nutrient uptake (Gobran et al., 1998; Mitchell et al., 2007). The complex interactions among host plants, environmental conditions and fungal communities are difficult to disentangle and the relative importance of the indirect host effects on this mutualistic relationship remains unclear. 
Oak forests of southern Spain are an important economic and social resource at the same time that they are a hotspot of endemic and relict plant species (Médail and Quézel, 1999; Anonymous, 2005). Despite the well-known dependence of oaks on mycorrhizal fungi, only a limited number of studies have been done on the belowground ECM communities in oak forests (Walker et al., 2005; Buée et al., 2007; Avis et al., 2008), and even fewer have been carried out in areas with seasonally dry Mediterranean-type climates (Richard et al., 2005; Smith et al., 2007; Morris et al., 2008). In this study we aimed to investigate the importance of the indirect effects of host tree species on the ECM community. For that purpose we studied the ECM fungal community on the roots of two coexisting oak trees, the sclerophyllous evergreen Quercus suber (cork oak) and the winter-deciduous Quercus canariensis (Algerian oak), under the Męditerranean-type climate of southern Spain, using PCR-based molecular methods.

The research objectives of this study were: i) to assess the diversity and structure of the ECM communities on the roots of these two co-occurring Quercus species in two Mediterranean mixed-oak forests, using DNA-based identification techniques; ii) to analyse the relationships between the distribution of ECM species and the measured litter and soil variables by using multivariate methods; iii) to evaluate the extent to which the composition and diversity of the ECM community may be explained by the soil conditions, the host identity and the litter-mediated changes in the topsoil environment (soil and litter) and iv) to compare among several alternative causal models explaining the plant-soil-fungal interactions, in order to test the hypothesis that the studied oak host species, through the differences in their leaf fall quality, may produce key changes in the litter and topsoil chemical composition that in turn, may affect the ECM community assemblage.

\section{Materials and methods}

\subsection{Study area and forest sites}

The study area is located in the Aljibe Mountains, in the south of Spain. The region has a rough topography, with the highest peak reaching $1092 \mathrm{~m}$ a.s.l. The bedrock dominated by Oligo-Miocene sandstone originates acidic, nutrient-poor soils (Palexeralfs; Soil Survey Staff, 2006) frequently interspersed with layers of marl sediments that yield soils richer in clay (Haploxererts; Soil Survey Staff, 2006). The climate is of the sub-humid Mediterranean-type with most rainfall (95\%) occurring from October to May. See detailed descriptions of the area in Ojeda et al. (2000), and Anonymous (2005).

The vegetation is dominated by evergreen cork oak ( $Q$. suber $L$.), mixed with the winter-deciduous Algerian oak ( $Q$. canariensis Willd.), which is locally abundant in the valley bottoms (Urbieta et al., 2008). The arborescent shrubs Phillyrea latifolia L. and Pistacia lentiscus L. dominated the understorey. The area has been protected since 1989 as "Los Alcornocales" (meaning "the cork oak forests") Natural Park (Anonymous, 2005).

Two structurally different forest sites, $40 \mathrm{~km}$ apart, were selected within the study area. The site at San Carlos del Tiradero $\left(36^{\circ} 9^{\prime} 46^{\prime \prime \prime} \mathrm{N} ; 5^{\circ} 35^{\prime} 39^{\prime \prime \prime} \mathrm{W}\right)$, hereafter called "Forest", was located in the south of the Park near the coast at $335-360 \mathrm{~m}$ a.s.l. on a NE facing slope. The mean annual rainfall is $964 \mathrm{~mm}$, and the mean annual air temperature is $16.6^{\circ} \mathrm{C}$, with a minimum of $4.1^{\circ} \mathrm{C}$. The Forest stand had a high density of trees ( 769 stems ha $^{-1}$ ) with a basal area of $47 \mathrm{~m}^{2} \mathrm{ha}^{-1}$ (estimated on trees with $\mathrm{dbh} \geq 1.6 \mathrm{~cm}$ ).

The other site, at La Sauceda $\left(36^{\circ} 31^{\prime} 54^{\prime \prime \prime} \mathrm{N} ; 5^{\circ} 34^{\prime} 29^{\prime \prime \prime} \mathrm{W}\right)$, hereafter called "Woodland", was located inland, in the north of the Park, at 530-560 m a.s.l. on a NW facing slope. It has a mean annual temperature of $15.5^{\circ} \mathrm{C}$, with a minimum of $1.8^{\circ} \mathrm{C}$ and a mean annual rainfall of $1470 \mathrm{~mm}$. The Woodland tree density was relatively low with 219 stems ha ${ }^{-1}$ and a basal area of $22 \mathrm{~m}^{2} \mathrm{ha}^{-1}$ (Pérez-Ramos et al., 2008)

\subsection{Sampling design}

At each forest site (f: Forest, w: Woodland), six adult individuals of $Q$. suber (S) and six of $Q$. canariensis (C) located in a matrix of coexisting oak species and spread across approximately 1 ha were selected. Thus a total of 24 oaks were sampled that can be grouped into four categories (Cf, Cw, Sf, Sw; each with six replicates) of two combined factors: oak species and forest site. The selected trees were estimated to be more than 50 years old.

Leaf fall, litter, topsoil ( $\sim 1400 \mathrm{~cm}^{3}, 0-25 \mathrm{~cm}$ depth) and subsoil ( $\sim 1400 \mathrm{~cm}^{3}, 25-50 \mathrm{~cm}$ depth) were sampled beneath the canopy of each selected oak at approximately $2 \mathrm{~m}$ from the trunk in November 2006. Annual leaf fall was collected by four traps $(50 \mathrm{~cm}$ diameter) located under each tree. The contents were removed, and the leaves were separated and dried. Two $30 \times 30 \mathrm{~cm}$ quadrats were sampled to assess the litter biomass, by the harvesting and drying method (expressed as kg dry mass $\mathrm{m}^{-2}$ ). Both leaf fall and litter samples were composed by leaves from one oak species since the closest neighbours of the selected trees were individuals of the same species and they had no significant understorey cover under their canopy. Once the litter layer was removed, cores of soil were extracted with a cylindrical auger; four samples of topsoil $(0-25 \mathrm{~cm})$ and four of subsoil $(25-50 \mathrm{~cm})$ were taken under each oak tree in the four cardinal directions and pooled into single representative samples.

Superficial roots $(\sim 0-15 \mathrm{~cm}$ depth) approximately equal in length $(\approx 20 \mathrm{~cm})$ were taken from each selected tree, close to the litter and soil sampling points, in November 2007. Root samples were kept moist in sealed plastic bags and transported inside an ice-box to the laboratory, where they were stored at $4{ }^{\circ} \mathrm{C}$. Within two days, each root system was examined under a binocular microscope, and 20-22 ectomycorrhizal root tips from each tree were randomly picked free of debris, removed with tweezers and individually stored frozen in $100 \mu \mathrm{l}$ of $2 \times$ CTAB buffer.

\subsection{Leaf fall, litter and soil analyses}

Samples of leaf fall and litter were dried at $70^{\circ} \mathrm{C}$, weighed, and ground for chemical analysis. Soil samples were dried $\left(30^{\circ} \mathrm{C}\right.$ for $48-72 \mathrm{~h}$ ) and crushed to pass through a $2 \mathrm{~mm}$ sieve. Soil acidity $(\mathrm{pH})$ was determined potentiometrically in a $1: 2.5$ soil: $\mathrm{H}_{2} \mathrm{O}$ solution. The percentage of soil carbon was estimated using a Total Organic Carbon Analyzer (TOC- $\mathrm{V}_{\text {esh }}$ ). The available $\mathrm{P}$ was estimated using the Bray 1method (Bray and Kurtz, 1945). The total concentration of several macro-nutrients ( $\mathrm{Ca}, \mathrm{K}, \mathrm{Mg}, \mathrm{P}$ and $\mathrm{S}$ ) in plant tissues and soils was determined by acid digestion with nitric acid or aqua regia followed by ICP-OES (Inductively Coupled Plasma Optical Emission Spectrometry). Plant and soil nitrogen was determined by using Kjeldahl digestion and subsequent distillation-titration in a Bran-Luebbe Autoanalyzer. See methods in Allen (1989).

\subsection{Ectomycorrhizal DNA extraction, amplification and sequencing}

From each ectomycorrhiza sampled, DNA was extracted using the Wizard Genomic DNA Purification Kit (Promega, Charbonnieres, France). The CTAB extraction buffer was removed, and the ectomycorrhizas were rinsed with sterile water. Two hundred microlitres of Nuclei Lysis Solution were added. Samples were ground into slurry using a micro-homogeniser with sterilised tips and then incubated for $15 \mathrm{~min}$ at $65^{\circ} \mathrm{C}$. Subsequently, $67 \mu \mathrm{l}$ of protein precipitation 
solution was added and vortexed. The mixture was centrifuged at $14,000 \mathrm{rpm}$ for $10 \mathrm{~min}$, and the supernatant containing DNA was moved to a fresh tube. The DNA was precipitated by isopropanol and resuspended overnight at $4{ }^{\circ} \mathrm{C}$ in nuclease free water.

Following extraction, the internal transcribed spacer regions I and II and the nuclear 5.8S rRNA gene were amplified using the primer sets ITS-1F/ITS-4B (Gardes and Bruns, 1993) or ITS-1F/ITS-4 (White et al., 1990) depending on amplification success. The PCR mixture for one sample was composed of $15.8 \mu \mathrm{l}$ of nuclease free water, $5 \mu \mathrm{l}$ of $10 \times$ Buffer, $0.25 \mu \mathrm{l}$ of each primer $(5 \mu \mathrm{M}), 5 \mu \mathrm{l}$ of deoxynucleotide triphosphate $(5 \mathrm{mM})$ and $0.2 \mu \mathrm{l}$ of GoTaq. Thermal cycling conditions were as follows: initial denaturalisation at $95^{\circ} \mathrm{C}$ for $1 \mathrm{~min}$; 35 cycles at $95^{\circ} \mathrm{C}$ for $1 \mathrm{~min}, 55^{\circ} \mathrm{C}$ for $1 \mathrm{~min}, 72^{\circ} \mathrm{C}$ for $1 \mathrm{~min}$; and a final elongation at $72{ }^{\circ} \mathrm{C}$ for $10 \mathrm{~min}$. PCR products were assessed by electrophoresis ( $30 \mathrm{~min}$ at $100 \mathrm{~W}$ on $1 \%$ agarose gels) before sequencing. Gels were stained with ethidium bromide and photographed under ultraviolet light. Unsuccessfully amplified samples were subjected to multiple attempts of PCR at various concentrations of template. The sequencing of the final amplification products was done by MilleGen (Labège, France). Nucleotide sequences were manually edited with the freeware program Chromas Lite 2.01 (http://www.technelysium. com.au/chromas.html).

\subsection{Ectomycorrhizal identification}

Ectomycorrhizal "operational taxonomic units" (OTUs) (Blaxter et al., 2005) were determined as follows: First, edited sequences were examined by BLAST searches against GenBank (http://www. ncbi.nlm.nih.gov/) and the UNITE database (http://unite.zbi.ee/; (Kõljalg et al., 2005)).

Few sequences shared $97 \%$ or greater similarity with any of the species deposited in GenBank or UNITE. This cut off level was established based on studies using the ITS region for ECM species identification that have shown that error rates generated by PCR, sequencing and interspecific variability are generally $\leq 3 \%$ (Nilsson et al., 2006). Due to the limited number of species identified by BLAST search the samples were grouped by the closest matching genus. For each genus group, sequences were aligned and analysed with MEGA4 (http://www.megasoftware.net/), and the p-distance (\% of different nucleotides) was calculated. This measure, although simple, is adequate when studying closely related distances (Nei and Kumar, 2000). Sequences with $\leq 3 \%$ of a difference in $p$-distance were ascribed to a single OTU. The complete name for a species was only given to those OTUs that match a GenBank species sequence by $\geq 97 \%$.

In order to test the grouping and identification of OTUs, phylogenetic trees were generated that included all of the sequences from the same genus and some identified sequences from GenBank as external taxonomic benchmarks. Two types of methods were used for the phylogenetic analysis: 1) the neighbourhood joining method with Kimura-2 distances and confidence assessed by bootstrapping with 500 replicates, and 2) the maximum parsimony method with a heuristic search, tree bisection-reconnection swapping, 100 replicates, gaps treated as 5th character and equal weight of characters methods (Bruns et al., 1998; Nei and Kumar, 2000). These analyses allowed us to test whether the groups identified based on $p$-distances were right and whether the correspondence of OTUs to identified GenBank species was correct. A last tree in which all of the sequences were analysed together confirmed the correct ascription of the OTUs to families and genera.

\subsection{Data analysis}

Mycorrhizal OTUs were categorised according to their taxonomy (division, order, family and genus) following the Index Fungorum ("www.indexfungorum.org" retrieved 22/06/2008), and fruiting habit, namely, epigeous (aboveground fruiting), hypogeous (belowground fruiting), resupinate (crust-like) and asexual. The abundance for each of these groups was the total number of mycorrhizal tips belonging to each class, while the relative abundance was calculated as the abundance of the group divided by the total number of identified symbionts. The independence in the frequency of categorical variables between oak species-site groups was assessed using the Yates corrected $\chi^{2}$ test, and the differences in the abundances of categories were compared using the Mann-Whitney $U$ test (as a nonparametric alternative for $t$-test). Occurrence was counted as the number of trees in which fungal OTUs were found.

Species (more precisely OTU) richness $(S)$ was measured as the number of species in a defined sampling unit. Rarefaction analysis was used to estimate the number of species expected in each sample if all samples were of a standard size, thus overcoming the effect of unequal numbers of identified mycorrhizas. The dominance of the community was assessed using Simpson's diversity index (1-D). Fisher's alpha $(\alpha)$ was also used to measure diversity because of its good discriminant ability and the fact that it is hardly influenced by sample size (Magurran, 1988). All indexes were calculated using Biodiversity Pro V.2 (http://www.sams.ac.uk/ research/software).

The taxonomic distinctness index $\left(\Delta^{*}\right)$, as defined by Warwick and Clarke (1995), was used to estimate the phylogenetic relatedness of the ECM species. It was calculated, based on the topology of a taxonomic tree, as the average path length between any two randomly chosen individuals, conditional on them being from different species. The phylogenetic structure of the ECM communities was statistically assessed using UNIFRAC (Lozupone et al., 2006). A phylogenetic tree was constructed using the neighbourjoining method and both the UniFrac distance metric (Lozupone and Knight, 2005), which is calculated based on differences in the tree branch length, and the $P$ test (Martin, 2002), which estimates similarity between communities based on tree topology, were used to detect differences in the ECM community composition between host species and forest sites.

The similarity of ectomycorrhizal fungal communities between oak trees and between sites was assessed with the Sorensen index. In order to take the distribution of species into account, similarity was also estimated based on abundance with the percentage similarity coefficient according to Jongman et al. (1995).

Two-way factorial ANOVAs using site and host species as categorical factors were performed for each of the measured environmental variables to ascertain if the overall environmental conditions differed significantly under the studied oak species and in both forest sites. When necessary, transformations (logarithmic, square root) were performed to satisfy the necessary assumptions (normality, homoscedasticity). The relationship between the ECM community composition and environmental conditions was analysed by a direct gradient analysis method, the Canonical Correspondence Analysis (CCA), using the Canoco for Windows 4.5 package. This unimodal ordination method was preferred over a linear one (redundancy analysis) since the unconstrained ordination (detrended correspondence analysis, DCA) of the species distribution data showed that they were largely heterogeneous, defining a long main gradient (ter Braak and Smilauer, 2002). Some rare species (singletons) distorted the analysis, producing deviant samples (outliers); thus, we performed the CCA analysis without singletons. Nevertheless, we compared the results with those derived from the analysis done with the complete set of ECM species. Species data were $\log (x+1)$ transformed to reduce skewness.

In order to investigate the overall patterns of covariation between the measured variables a d-sep method of path analysis 
(Shipley, 2000) was used to test for alternative causal models linking the tree (leaf, leaf fall, litter, host identity), soil (topsoil and subsoil) and the ECM fungal community. Each alternative model entails a series of causal assumptions related to the implications of the model for the variances and covariances of the variables that can be tested against the obtained empirical data. A model fits the data when these assumptions can not be falsified (i.e. $p>0.05$ ). As a surrogate of the overall ECM community composition we used the main independent gradient of variation extracted with an unconstrained correspondence analysis (CA) on the ECM species data. The $\mathrm{CA}$ analysis guaranteed no influence of the environmental variables on gradient selection. Because most variables were not normally distributed we used Spearman correlations in the analysis, for which data was converted to rank.

Since different sets of repeated tests were performed throughout the study a type I error inflation was expected (see García, 2004). To cope with this increased frequency of spurious results, while minimising power losses associated to Bonferroni-related procedures, we controlled the expected proportion of 'false positives' using a FDR (False Discovery Rate) controlling procedure as recommended by García (2003).

\section{Results}

\subsection{ECM community in a Mediterranean forest}

A total of 69 different species (OTUs) were identified from the root tips sampled, belonging to 24 genera and 18 families. A detailed list of the identified OTUs is presented in the Supporting Information Table S1. Basidiomycetes dominated the fungal communities on roots of both oak trees ( $>90 \%$ of all identified mycorrhizas) and were present in virtually all sampled trees (23 out of 24). Ascomycetes were scarce, accounting for only 10 mycorrhizas ( $5 \%$ of total abundance), but they were relatively widespread, occurring in 10 of the 24 trees sampled and in both oak species and forest stands. Both fungal groups were similarly distributed among the two oak species and sites ( $p>0.85$; based on Yates corrected $\chi^{2}$ test).

Thelephoraceae was the most diverse family (comprising $28 \%$ of the species), followed by Russulaceae (22\%) and Cortinariaceae (17\%). Eighteen of the 24 identified genera were comprised of only two species. Tomentella and Russula were the most widespread and abundant taxa. The most frequent OTUs were Lactarius chrysorrheus (found on seven trees) and Cenococcum geophilum (on six trees), which attained $6 \%$ and $3 \%$ of the total abundance, respectively. Two-thirds of the identified ECM were singletons, occurring only in one sample.
ECM fungal species with epigeous fruiting bodies were the most diverse (55\% of the species) and abundant (60\% of identified mycorrhizas) followed by resupinate fungi that attained 27 species and $33 \%$ of the total abundance. Hypogeous fungi were scant (3\%), and they were rarely found (in 5 oak trees). The frequencies of fruiting habits varied between sites and oak species (Yates corrected $\left.\chi^{2}, p<0.03\right)$.

The total number of ECM species associated with oak trees was similar for the two Quercus species in both study sites (Table 1). Rarefaction analysis indicated a lower diversity of ECM species in the Forest than in the Woodland site, irrespective of the host species (Fig. 1). Other indices, such as the Simpson's diversity index or Fisher's alpha, confirmed this tendency (Table 1). Equal numbers of families (14) and genera (18) were found on roots of both oak species; however, the taxonomic distinctness values were lower for the fungal species colonising the roots of the Algerian oak (Q. canariensis) in the Woodland. These results were in agreement with the UniFrac analysis, which suggested that there were significant community shifts between environments overall (UniFrac metric $p<0.026$ ). Lineage specific analysis revealed that these differences were primarily because of the tomentelloids and russuloids which differed significantly $(p<0.000)$ between the four oak-site environments. The ECM community on the roots of Q. canariensis in the Woodland site $(\mathrm{CW})$ was dominated by Tomentella (53\% of identified mycorrhizas), followed by Cortinarius (15\%). In contrast, Russula was the most abundant taxon $(\approx 35 \%$ of the symbionts) on the other three species-site combinations (Cf, Sw and Sf). The community on $Q$. suber in the Forest site (Sf) was dominated by three russuloids, Russula (30\%, already mentioned), Lactarius (14\%) and Macowanites (10\%) (Fig. 2).

Among the 69 identified fungal species, only 13 were found on both Quercus species, e.g.r. C. geophilum, Otidea sp1. and Byssocorticium atrovirens, while 29 were recorded exclusively on Q. canariensis roots, and 27 species occurred only on $Q$. suber. The limited number of common fungal species between trees resulted in low Sorensen similarity values that ranged from 0.13 to 0.39 (Table 1). Communities from Sf and Cf roots were 35\% of similar, and both had about a $17 \%$ similarity with Sw. The most dissimilar ECM community was that on the roots of $\mathrm{CW}(\approx 6 \%)$, which only shared 4 species with the other groups.

\subsection{Environmental heterogeneity: oak species and site factors}

There were significant differences between forest sites and oak host species for some of the measured environmental variables (Table 2). Soil $\mathrm{Ca}$ and $\mathrm{pH}$ exhibited highly significant $(p<0.005)$ additive effects for both site and oak species. It is remarkable that

Table 1

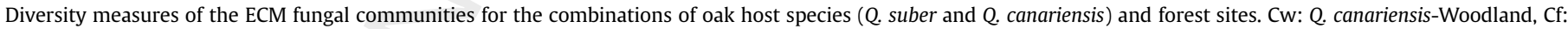
Q. canariensis-Forest, Sw: Q. suber-Woodland, and Sf: Q. suber-Forest.

\begin{tabular}{|c|c|c|c|c|c|}
\hline \multirow[t]{2}{*}{ Diversity measure } & \multicolumn{2}{|l|}{ Woodland } & \multicolumn{2}{|l|}{ Forest } & \multirow[t]{2}{*}{ All trees } \\
\hline & Q. canariensis & Q. suber & Q. canariensis & Q. suber & \\
\hline Species richness $(\mathrm{S})$ & 22 & 25 & 23 & 23 & 69 \\
\hline Species density (average spp./per tree) & 4.0 & 4.8 & 4.5 & 6.3 & 4.9 \\
\hline Simpson's diversity index (1-D) & 0.954 & 0.954 & 0.873 & 0.935 & 0.965 \\
\hline Rarefaction species richness $(n=38)$ & 22.00 & 21.53 & 17.35 & 17.45 & \\
\hline Fisher's alpha $(\alpha)$ & 21.8 & 21.0 & 14.3 & 11.9 & 35.4 \\
\hline Taxonomic distinctness $(\Delta)$ & 2.97 & 3.45 & 3.28 & 3.25 & 3.44 \\
\hline Singleton species & 20 & 19 & 21 & 15 & 46 \\
\hline \multicolumn{6}{|l|}{ Similarity index } \\
\hline Between sites: & 0.13 & 0.33 & & & \\
\hline $\mathrm{Cw}-\mathrm{Cf} / \mathrm{Sw}-\mathrm{Sf}$ & & & & & \\
\hline $\begin{array}{l}\text { Between species: } \\
\text { Cw-Sw/Cf-Sf }\end{array}$ & 0.13 & & 0.39 & & \\
\hline
\end{tabular}




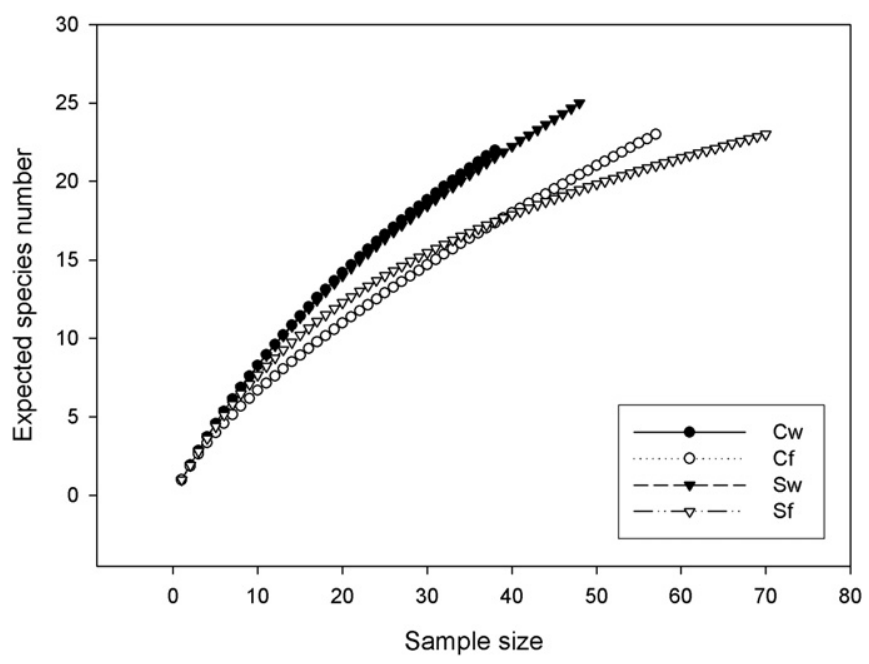

Fig. 1. Rarefaction estimation of ECM fungal species richness on roots of Quercus suber and $Q$. canariensis. Cw: Q. canariensis-Woodland; Cf: $Q$. canariensis-Forest; Sw: Q. suberWoodland; Sf: Q. suber-Forest. Sample size is number of ectomycorrhizas.

litter Ca was the only factor showing both high significant additive and multiplicative (site $\times$ oak) effects.

Litter and topsoil sampled under the canopy of the winterdeciduous species ( $Q$. canariensis) were significantly richer in $\mathrm{Ca}$, and the soils were less acidic than those sampled under the evergreen oaks (Table 2). These results were consistent with the differences found in the amount and composition of the leaf fall collected during a whole year under both species (Table 2, third panel), in which Ca was the only element significantly enriched (51\% higher) in the leaf fall from the winter-deciduous species. The level of this leaf fall enrichment essentially depended on the oak species because the effects of site and site $\times$ oak were not significant.

Regarding the relationships among environmental variables, some very high $(r \geq 0.9)$ correlations between litter $\mathrm{Ca}$, soil $\mathrm{pH}$ and soil Ca contents were detected, as well as high correlations $(r=0.8-0.9)$ between other several soil and litter variables (Table 3).

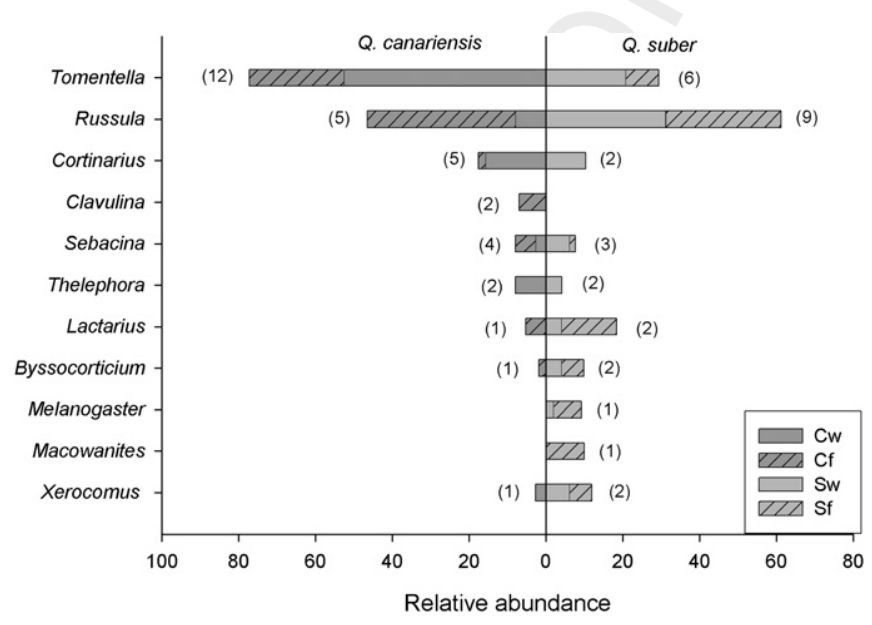

Fig. 2. Relative abundance of the most abundant ectomycorrhizal genera on Algerian oak ( $Q$. canariensis (C), in the left panel), and cork oak (Q. suber (S), in the right panel). The results are grouped by oak host species and forest site (f: Forest, w: Woodland). The number of species per genus is indicated between brackets for each Quercus species.

\subsection{ECM community_environment relationships}

The distribution of the ECM species was explained by significant conditional effects of the forest site $(p<0.023)$, the host oak species $(p<0.038)$ and the site $\times$ host interaction $(p<0.036)$, as shown by the factorial CCA. The overall CCA factorial model explained $19.6 \%$ of the total ECM species variance and was highly significant $(p<0.0023)$.

When the measured topsoil variables were used as predictors of the ECM species distribution alone, only two variables showed highly significant $(p<0.01)$ marginal effects: soil $\mathrm{pH}(p<0.0007)$ and soil Ca content $(p<0.0041)$. Because of the very high correlation between these two variables (Table 3 ) only the $\mathrm{pH}$ had a significant conditional effect and thus was retained as the best predictor. This soil variable alone was able to explain $8.2 \%$ of the overall ECM species variance.

On the other hand, when the litter variables were used in the CCA analysis only litter Ca showed a highly significant $(p<0.01)$ conditional effect as a predictor of the ECM community structure. Furthermore, when both the soil and litter variables were included in the analysis, the model based on litter Ca content alone $(p<0.0002,8.4 \%$ overall variance explained) outperformed all other CCA models based on any combination of the remaining measured soil and litter variables, including soil $\mathrm{pH}$. The close relationship between litter $\mathrm{Ca}$ and soil $\mathrm{pH}$ (Table 3 ) and the better predictive performance of the litter Ca explained why only this variable was retained as a meaningful predictor of the ECM community structure.

In order to ascertain whether the hypothesised interactions between host species, soil and litter conditions and ECM fungal communities had a significant empirical support we used d-sep analysis to test different alternative causal models which underlying hypothesis were: 1) Main variations in the ECM communities may be explained by soil changes derived only from differences in intrinsic soil properties (subsoil), 2) Only host identity affects the ECM community composition by means of a direct genetic specificity, 3) There is a species indirect effect via differential leaf, leaf fall and litter quality that explains the main ECM variation patterns and 4) The combination of direct and indirect species effects and the primary soil properties drives the ECM community composition. All path diagrams corresponding to the proposed models are shown in Fig. 3. Calcium concentration in leaves, leaf fall, litter, topsoil and subsoil were used as surrogate variables in the models.

Table 4 includes the results of the analysis of the tested causal models. Only models explicitly considering the indirect effects of host species on ECM communities, via changes in litter (or litter and topsoil) composition matched the overall available empirical evidence (Fig. 3). Nevertheless the model based on simultaneous direct and indirect host influence was clearly more consistent with the empirical evidence $(p=0.21)$ than the one supported only by indirect effects $(p=0.06)$. All the models considering the independent influence of primary soil properties on the ECM communities were rejected.

\subsection{Environmental conditions and diversity of the ECM communities}

The overall mycorrhizal species richness increased significantly with soil acidity $(r=0.58, p<0.003)$. Negative relationships were found between the number of ECM genera and families and the litter Ca concentration $(r=-0.43, p<0.034)$ indicating a significantly lower taxonomic diversity with increasing Ca availability and soil $\mathrm{pH}$.

The distribution of taxa according to their fruiting habit was also significantly related to environmental conditions. The diversity and 
Table 2

The mean, standard error and $p$-values resulting from two-way ANOVA analyses for environmental and complementary variables measured in the topsoil, litter (L-) and leaf fall (F-) samples collected under the canopy of the two oak host species in the two forest sites. Complementary information on green leaves and subsoil is provided in the lowest panel. The $p$-values that remained significant after applying a tablewise FDR correction are in bold, and those that are additionally significant on a per-test basis $(p<0.05)$ are in italics.

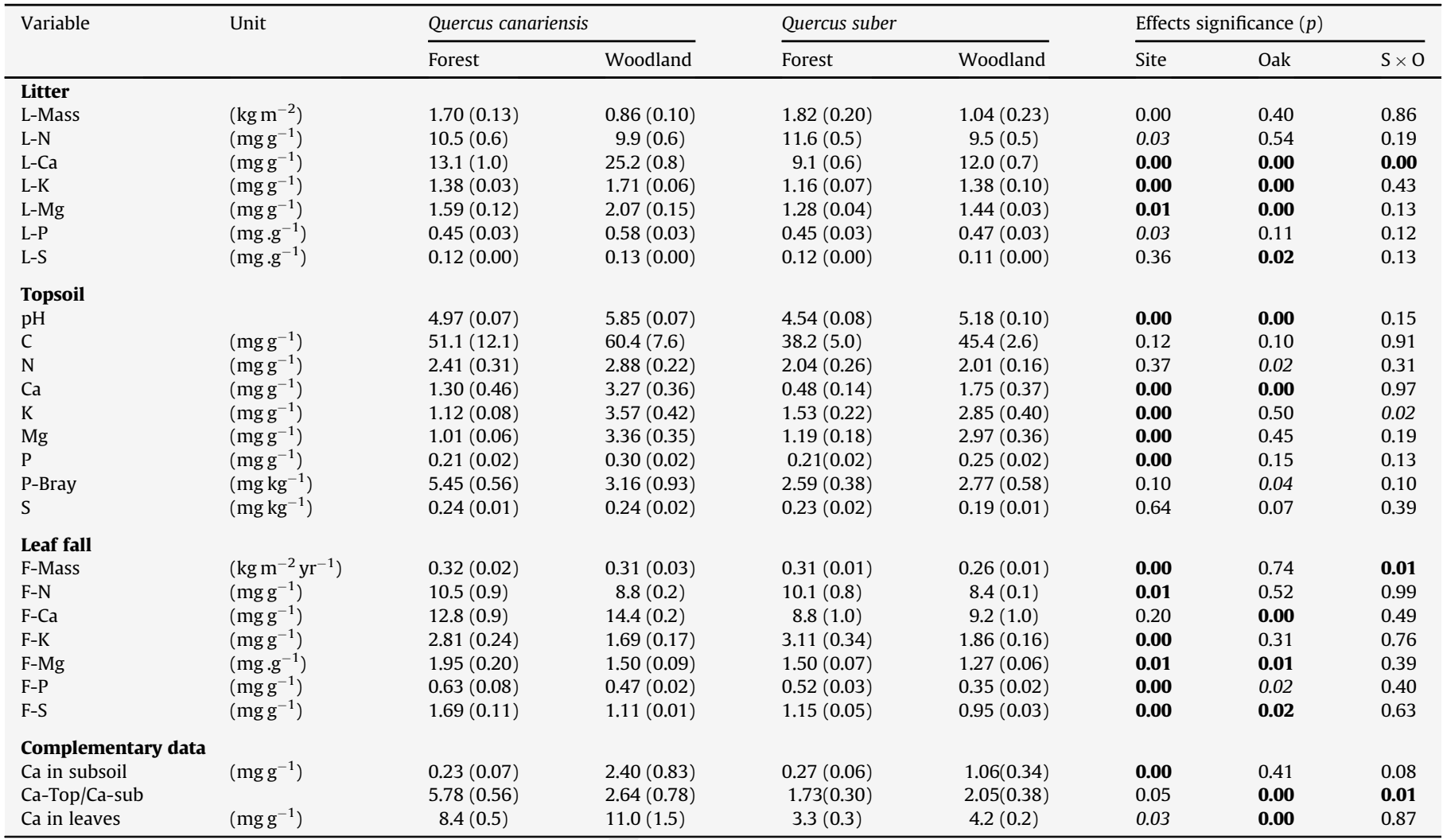

abundance of epigeous populations was negatively correlated with Ca in litter $(r \approx-0.50, p<0.03)$ and soil $\mathrm{pH}(r \approx-0.57, p<0.03)$. The opposite pattern was observed for resupinate species, for which richness rose along the gradient of Ca in litter $(r=0.44$, $p<0.03)$ and soil $\mathrm{pH}(r=0.47, p<0.02)$.

\section{Discussion}

\subsection{ECM fungal communities in a Mediterranean forest}

We have found that southern Spain oak forests harbour a relatively high ECM fungal species richness: 69 OTUs belonging to 24 genera and 18 families were identified in the roots of two oak species in two forest sites. These richness values are in accordance with others found in oak forests (ranges from 39 to 79; (Avis et al.,

Table 3

High correlations $(\bullet=0.8-0.9, \bullet \bullet>0.9)$ found between soil and litter (L-) variables. All marked correlations were positive.

\begin{tabular}{llllllllll}
\hline & $\mathrm{L}-\mathrm{Ca}$ & $\mathrm{L}-\mathrm{K}$ & $\mathrm{L}-\mathrm{Mg}$ & $\mathrm{pH}$ & $\mathrm{C}$ & $\mathrm{N}$ & $\mathrm{Ca}$ & $\mathrm{K}$ & $\mathrm{Mg}$ \\
\hline $\mathrm{L}-\mathrm{K}$ & $\bullet$ & & & & & & & & \\
$\mathrm{L}-\mathrm{Mg}$ & $\bullet$ & $\bullet$ & & & & & & & \\
$\mathrm{pH}$ & $\bullet \bullet$ & & & & & & & & \\
$\mathrm{C}$ & & & & & & & & & \\
$\mathrm{N}$ & & & $\bullet$ & $\bullet$ & $\bullet$ & & & & \\
$\mathrm{Ca}$ & $\bullet \bullet$ & & $\bullet$ & $\bullet$ & & & & & \\
$\mathrm{K}$ & & & & $\bullet$ & & & & & \\
$\mathrm{Mg}$ & & & & $\bullet$ & & $\bullet$ & $\bullet$ & $\bullet$ & $\bullet$ \\
$\mathrm{P}$ & & & & & & $\bullet$ & $\bullet$ \\
\hline
\end{tabular}

2003; Walker et al., 2005), although lower than the maximum values of 95-140 taxa recorded in some Mediterranean forests (Richard et al., 2004; Morris et al., 2008). The species-area curve obtained here (Fig. 1) indicates that the local ECM fungal biodiversity must be even higher. We found a large number of rare taxa (46 singleton species) that is a common feature in ECM fungal communities (Kõljalg et al., 2000; Avis et al., 2008)).

Thelephoraceae (28\% of the species), Russulaceae (22\%) and Cortinariaceae (17\%) were the most diverse and abundant families in the ECM fungal communities, as has also been found in other forests (Gardes and Bruns, 1996; Richard et al., 2005; Riviere et al., 2007). In a similar study, Morris et al. (2008) investigated the ECM fungal community on the root of two coexisting oak species in a California woodland, and found a large abundance of Ascomycota (40\%) and hypogeous fruiting fungi ( $25 \%$ ). In contrast, a low abundance of this groups was recorded in Mediterranean Quercus forests of south Spain (this study) and Corsica (Richard et al. (2005)). These strong differences between ECM fungal communities on similar oak species and under Mediterranean-type climate, but in distant biogeographical regions (California versus Mediterranean Basin), are worth to be studied in more detail. The Ascomycota species C. geophilum, which is a known associate of Quercus roots (Dickie et al., 2004; Walker et al., 2005), only represented 3\% of the total abundance in the forests studied. The relative humidity and high precipitation level in the study sites may negatively impact the colonisation and spread of this drought tolerant fungus (Pigott, 1982). In addition, the small size of $C$. geophillum ECM tips may cause the unsuccessful amplification of their DNA and thus, result in their under-representation (Smith et al., 2007). 


\section{Table 4}

Shipley's d-sep test results of different causal models which could potentially explain the observed covariation patterns among host species ( $Q$. canariensis, $Q$. suber), Ca content in different forest compartments (green leaves, leaf fall, litter fall, subsoil and topsoil) and ECM fungal community structure (summarised by the main axis extracted by correspondence analysis from the ECM data).

\begin{tabular}{|c|c|c|c|c|}
\hline Model & Chi-sq & d.f. & $p$ & Tested effect \\
\hline 1 & 92.05 & 30 & 0.0000 & Direct effect of soil intrinsic properties \\
\hline 2 & 32.80 & 20 & 0.0354 & Direct effect of host genetic specificity \\
\hline 3 & 28.30 & 18 & 0.0577 & $\begin{array}{l}\text { Indirect effect of host species via leaf } \\
\text { fall and litter quality }\end{array}$ \\
\hline 4 & 20.16 & 16 & 0.2131 & Direct and indirect effects of host species \\
\hline 5 & 56.68 & 28 & 0.0011 & $\begin{array}{l}\text { Direct effect of soil intrinsic properties } \\
\text { and indirect effect of host species }\end{array}$ \\
\hline 6 & 43.50 & 26 & 0.0171 & $\begin{array}{l}\text { Direct effect of soil intrinsic properties and } \\
\text { direct and indirect effects of host species }\end{array}$ \\
\hline
\end{tabular}

significantly more Ca than the coexisting evergreen species (Q. suber) leading to a top-down cascading effect by which the relative Ca enrichment in the materials collected under the winterdeciduous species in comparison to the evergreen $Q$. suber increased from leaf fall (51\% higher) to litter ( $81 \%$ higher) to topsoil (251\% higher). We suggest that the differences in leaf fall Ca-levels, and their yearly accumulation and incorporation into the litter, yield increasingly distinct litter and topsoil, thus producing selective environmental conditions that shape the ECM fungal community. The observed shift in the dominant taxa from russuloids to tomentelloids was the most outstanding change associated with the oak-induced variation in the environmental conditions and it was observed in the two forest sites despite their contrasting environmental conditions.

Leaf fall calcium content is a tree species-specific trait that depends on their uptake, allocation and retention capacity; thus, even species growing under similar subsoil nutrient supplies, as it occurred in the studied forests, in time, distinctly modify their soil abiotic environments (Reich, 2005). Leaf fall Ca determines litter Ca, which has a strong relationship with forest floor biogeochemical dynamics such as soil acidity, base saturation, $\mathrm{C}$ and $\mathrm{N}$ contents, decomposition rates and soil heterotrophic community composition (Reich, 2005; Hobbie et al., 2006). Since soil pH was closely correlated to calcium levels in soil and litter, and since it was also a significant predictor for ECM fungal species distribution, calciuminduced changes in soil acidity seem to play a main role in determining the observed differences in the fungal communities between environments. The relationship between shifts in ECM fungal species communities and soil $\mathrm{pH}$ has been previously described: Soil acidity seems to have a species-specific effect on the production of fruiting bodies (Agerer et al., 1998). In vitro experiments have shown that substrate $\mathrm{pH}$ affects the growth capacity (Hung and Trappe, 1983), mycelial density (Rosling et al., 2004), colonisation potential (Erland and Soderstrom, 1990) and enzymatic capabilities (Courty et al., 2005) of mycorrhizal species. Changes in the performance of species under different $\mathrm{pH}$ levels affect their competitive abilities (McAfee and Fortin, 1987), altering their relative abundance in the community. However these changes 
were treated as an abiotic host-independent influence and were not related to host indirect effects through leaf fall or litter quality.

\subsection{ECM fungal diversity and soil conditions}

No significant changes in ECM fungal species richness were observed between oak species, and forest sites. However, the taxonomic diversity (number of genera and families) and the phylogenetic structure of the community significantly shifted. Other studies have also found changes in species dominance from epigeous to resupinate (Peter et al., 2001), and from Basidiomycetes to Ascomycetes (Gehring et al., 1998) related to variations in soil conditions (e.g. increase in nutrient availability). Differences in the abundance and diversity of epigeous species between the roots of evergreen and deciduous coexisting oaks were also recently observed by Morris et al. (2008).

The lower ECM fungal taxonomic diversity recorded on the roots of $Q$. canariensis in the Woodland site was mainly due to both the higher abundance of resupinate tomentelloid species and the disappearance of epigeous taxa. It is possible that the prevailing environmental conditions, i.e. higher litter, and soil nutrient content and $\mathrm{pH}$, may be limiting for certain fungal species (e.g. Russula) and thus represent an environmental filter yielding a phylogenetic clustering of closely related "tolerant" species such as the tomentelloids.

Environmental selection for biological traits conferring tolerance and selection for competitive interactions that promote functional diversification are two of the main processes that govern the phylogenetic structures of animal, plant and bacterial communities (Fox and Brown, 1993; Weiher and Keddy, 1995; Horner-Devine and Bohannan, 2006). The relationships that we have found between ECM fungal taxonomic diversity and soil conditions in thesemixed-oak forests suggest that these complementary ecological processes might also drive the community structure of mycorrhizal fungi.

\section{Conclusions}

Our work suggests that leaf fall-mediated indirect hos $\iota^{\curlywedge}$ effects may play a critical role in determining the ECM fungal community assemblage and taxonomic diversity. These effects could have been interpreted either as pure environmental effects (host-independent), if the relationships between soil properties and the host source materials (leaf fall, litter) had not been simultaneously investigated, or as a generic mixed host-site effect, if only a factorial multivariate analysis had been performed. To our knowledge this is the first attempt to investigate the indirect effect of host species on ECM fungal assemblages. Since this interaction had been previously unnoticed and seems to be superimposed to direct host effects, further work is needed to unveil its relative importance as a driving factor of the ECM fungal communities.

\section{Acknowledgements}

We thank the Consejería de Medio Ambiente (Andalusian Government) and Marco Antonio Tena, then Director of Los Alcornocales Natural Park, for the facilities and support to carry out our field work. We are grateful to Nacho Pérez-Ramos, Ana Pozuelos, María Navarro, Eduardo Gutiérrez, Sophie Manzi and Juliet Rochet for field and lab assistance. This study was supported by an FPI-MEC grant to CA, by the Spanish MEC projects Dinamed (CGL2005-5830C03-01) and Interbos (CGL2008-4503-C03-01), and the European FEDER funds. This research is part of the Globimed (www. globimed.net) network in forest ecology.

\section{Appendix. Supplementary information}

Supplementary data associated with this article can be found in the online version at doi:10.1016/j.soilbio.2010.01.014.

\section{References}

Agerer, R., Taylor, A.F.S., Treu, R., 1998. Effects of acid irrigation and liming on the production of fruit bodies by ectomycorrhizal fungi. Plant and Soil 199, 83-89.

Allen, S.E., 1989. Chemical Analysis of Ecological Materials. Blackwell, Oxford, UK. Anonymous, 2005. PORN/PRUG/PDS Parque Natural Los Alcornocales. Junta de Andalucía, Consejería de Medio Ambiente, Sevilla, España.

Avis, P.G., Mueller, G.M., Lussenhop, J., 2008. Ectomycorrhizal fungal communities in two North American oak forests respond to nitrogen addition. New Phytologist 179, 472-483.

Avis, P.G., McLaughlin, D.J., Dentinger, B.C., Reich, P.B., 2003. Long-term increase in nitrogen supply alters above- and below-ground ectomycorrhizal communities and increases the dominance of Russula spp. in a temperate oak savanna. New Phytologist 160, 239-253.

Bennett, L.T., Kasel, S., Tibbits, J., 2009. Woodland trees modulate soil resources and conserve fungal diversity in fragmented landscapes. Soil Biology and Biochemistry 41, 2162-2169.

Blaxter, M., Mann, J., Chapman, T., Thomas, F., Whitton, C., Floyd, R., Abebe, E., 2005 Defining operational taxonomic units using DNA barcode data. Philosophical Transactions of the Royal Society B: Biological Sciences 360, 1935-1943.

Bray, R.H., Kurtz, L.T., 1945. Determination of total, organic and available forms of phosphorous in soils. Soil Science 59, 39-45.

Brearley, F.Q., 2006. Differences in the growth and ectomycorrhizal community of Dryobalanops lanceolata (Dipterocarpaceae) seedlings grown in ultramafic and non-ultramafic soils. Soil Biology and Biochemistry 38, 3407-3410.

Bruns, T.D., Szaro, T.M., Gardes, M., Cullings, K.W., Pan, J.J., Taylor, D.L., Horton, T.R., Kretzer, A., Garbelotto, M., Li, Y., 1998. A sequence database for the identification of ectomycorrhizal basidiomycetes by phylogenetic analysis. Molecular Ecology 7, 257-272.

Buée, M., Courty, P.E., Mignot, D., Garbaye, J., 2007. Soil niche effect on species diversity and catabolic activities in an ectomycorrhizal fungal community. Soil Biology and Biochemistry 39, 1947-1955.

Cavender-Bares, J., Izzo, A., Robinson, R., Lovelock, C.E., 2009. Changes in ectomycorrhizal community structure on two containerized oak hosts across an experimental hydrologic gradient. Mycorrhiza 19, 133-142.

Conn, C., Dighton, J., 2000. Litter quality influences on decomposition, ectomycorrhizal community structure and mycorrhizal root surface acid phosphatase activity. Soil Biology \& Biochemistry 32, 489-496.

Courty, P.-E., Pritsch, K., Schloter, M., Hartmann, A., Garbaye, J., 2005. Activity profiling of ectomycorrhiza communities in two forest soils using multiple enzymatic tests. New Phytologist 167, 309-319.

Dickie, I.A., Reich, P.B., 2005. Ectomycorrhizal fungal communities at forest edges. Journal of Ecology 93, 244-255.

Dickie, I.A., Guza, R.C., Krazewski, S.E., Reich, P.B., 2004. Shared ectomycorrhizal fungi between a herbaceous perennial Helianthemum bicknellii and oak Quercus seedlings. New Phytologist 164, 375-382.

Egerton-Warburton, L.M., Querejeta, J.I., Allen, M.F., 2007. Common mycorrhizal networks provide a potential pathway for the transfer of hydraulically lifted water between plants. Journal of Experimental Botany 58, 1473-1483.

Erland, S., Soderstrom, B., 1990. Effects of liming on ectomycorrhizal fungi infecting Pinus sylvestris L. I. Mycorrhizal infection in limed humus in the laboratory and isolation of fungi from mycorrhizal roots. New Phytologist 115, 675-682.

Finlay, R.D., 2008. Ecological aspects of mycorrhizal symbiosis: with special emphasis on the functional diversity of interactions involving the extraradical mycelium. Journal of Experimental Botany 59, 1115-1126.

Finzi, A.C., Canham, C.D., Van Breemen, N., 1998. Canopy tree-soil interactions within temperate forests: species effects on $\mathrm{pH}$ and cations. Ecological Applications $8,447-454$

Fox, B.J., Brown, J.H., 1993. Assembly rules for functional groups in North American desert rodent communities. Oikos 67, 358-370.

Frey-Klett, P., Chavatte, M., Clausse, M.-L., Courrier, S., Roux, C.L., Raaijmakers, J. Martinotti, M.G., Pierrat, J.-C., Garbaye, J., 2005. Ectomycorrhizal symbiosis affects functional diversity of rhizosphere fluorescent pseudomonads. New Phytologist $165,317-328$.

García, L.V., 2003. Controlling the false discovery rate in ecological research. Trends in Ecology and Evolution 18, 553-554.

García, L.V., 2004. Escaping the Bonferroni iron claw in ecological studies. Oikos 105, 657-663.

Gardes, M., Bruns, T.D., 1993. ITS primers with enhanced specificity for basidiomycetes - application to the identification of mycorrhizae and rusts. Molecular Ecology 2, 113-118.

Gardes, M., Bruns, T.D., 1996. Community structure of ectomycorrhizal fungi in a Pinus muricata forest: above- and below-ground views. Canadian Journal of Botany 74, 1572-1583.

Gehring, C.A., Theimer, T.C., Whitham, T.G., Keim, P., 1998. Ectomycorrhizal fungal community structure of pinyon pines growing in two environmental extremes. Ecology 79, 1562-1572. 
Gobran, G.R., Clegg, S., Courchesne, F., 1998. Rhizospheric processes influencing the biogeochemistry of forest ecosystems. Biogeochemistry 42, 107-120.

Hobbie, S.E., 1992. Effects of plant species on nutrient cycling. Trends in Ecology and Evolution 7, 336-339.

Hobbie, S.E., Reich, P.B., Oleksyn, J., Ogdahl, M., Zytkowiak, R., Hale, C. Karolewski, P., 2006. Tree species effects on decomposition and forest floor dynamics in a common garden. Ecology 87, 2288-2297.

Horner-Devine, M.C., Bohannan, B.J.M., 2006. Phylogenetic clustering and overdispersion in bacterial communities. Ecology 87, 100-108.

Hung, L.-L., Trappe, J., 1983. Growth variation between and within species of ectomycorrhizal fungi in response to $\mathrm{pH}$ in vitro. Mycologia 75, 234-241.

Ishida, T.A., Nara, K., Hogetsu, T., 2007. Host effects on ectomycorrhizal fungal communities: insight from eight host species in mixed coniferous \& broadleaf forests. New Phytologist 174, 430-440.

Jones, C.G., Lawton, J., Shachak, M., 1994. Organisms as ecosystem engineers. Oikos 69, 373.

Jongman, R.H.G., Braak, C.J.F.t., Tongeren, O.F.R.v., 1995. Data Analysis in Community and Landscape Ecology. Cambridge University Press, Cambridge, UK.

Kõljalg, U., Dahlberg, A., Taylor, A.F.S., Larsson, E., Hallenberg, N., Stenlid, J. Larsson, K.H., Fransson, P.M., Kårén, O., Jonsson, L., 2000. Diversity and abundance of resupinate thelephoroid fungi as ectomycorrhizal symbionts in Swedish boreal forests. Molecular Ecology 9, 1985-1996.

Kõljalg, U., Larsson, K.-H., Abarenkov, K., Nilsson, R.H., Alexander, I.J., Eberhardt, U. Erland, S., Høiland, K., Kjøller, R., Larsson, E., Pennanen, T., Sen, R., Taylor, A.F.S., Tedersoo, L., Vrålstad, T., Ursing, B.M., 2005. UNITE: a database providing webbased methods for the molecular identification of ectomycorrhizal fungi. New Phytologist 166, 1063-1068.

Lozupone, C., Knight, R., 2005. UniFrac: a new phylogenetic method for comparing microbial communities. Appl Environ Microbiol 71, 8228-8235.

Lozupone, C., Hamady, M., Knight, R., 2006. UniFrac - an online tool for comparing microbial community diversity in a phylogenetic context. BMC Bioinformatics 7 (7), 371.

Magurran, A.E., 1988. Ecological Diversity and its Measurement. University Press, Cambridge, UK

Martin, A., 2002. Appl. Environ. Microbiol. 68, 3673-3682.

McAfee, B.J., Fortin, J.A., 1987. The influence of $\mathrm{pH}$ on the competitive interactions of ectomycorrhizal mycobionts under field conditions. Canadian Journal of Forest Research 17, 859-864.

Médail, F., Quézel, P., 1999. Biodiversity hotspots in the Mediterranean Basin: setting global conservation priorities. Conservation Biology 13, 1510-1513.

Mitchell, R.J., Campbell, C.D., Chapman, S.J., Osler, G.H.R., Vanbergen, A.J., Ross, L.C. Cameron, C.M., Cole, L., 2007. The cascading effects of birch on heather moorland: a test for the top-down control of an ecosystem engineer. Journal of Ecology 93, 540-554.

Morris, M.H., Smith, M.E., Rizzo, D.M., Rejmanek, M., Bledsoe, C.S., 2008. Contrasting ectomycorrhizal fungal communities on the roots of co-occurring oaks (Quercus spp.) in a California woodland. New Phytologist 178, 167-176.

Nara, K., 2006. Ectomycorrhizal networks and seedling establishment during early primary succession. New Phytologist $169,169-178$.

Nei, M., Kumar, S., 2000. Molecular Evolution and Phylogenetics. Oxford University Press, New York, 333 pp.

Nilsson, R.H., Ryberg, M., Kristiansson, E., Abarenkov, K., Larsson, K.-H., KÃuljalg, U. 2006. Taxonomic reliability of DNA sequences in public sequence databases: a fungal perspective. PLoS ONE 1, e59.

Ojeda, F., Marañón, T., Arroyo, J., 2000. Plant diversity patterns in the Aljibe Mountains (S. Spain): a comprehensive account. Biodiversity and Conservation 9, 1323-1343.

Pérez-Ramos, I.M., Zavala, M.A., Marañón, T., Díaz-Villa, M.D., Valladares, F., 2008. Dynamics of understorey herbaceous plant diversity following shrub clearing of cork oak forests: a five-year study. Forest Ecology and Management 255, $3242-3253$.
Perry, D.A., Margolis, H., Choquette, C., Molina, R., Trappe, J.M., 1989. Ectomycorrhizal mediation of competition between coniferous tree species. New Phytologist 112, 501-511.

Peter, M., Ayer, F., Egli, S., 2001. Nitrogen addition in a Norway spruce stand altered macromycete sporocarp production and below-ground ectomycorrhizal species composition. New Phytologist 149, 311-325.

Pigott, C.D., 1982. Survival of mycorhiza formed by Cenococcum geophilum Fr. in dry soils. New Phytologist 92, 513-517.

Reich, P.B., 2005. Linking litter calcium, earthworms and soil properties: A common garden test with 14 tree species. Ecology Letters 8, 811-818.

Richard, F., Moreau, P.A., Selosse, M.A., Gardes, M., 2004. Diversity and fruiting patterns of ectomycorrhizal and saprobic fungi in an old-growth Mediterranean forest dominated by Quercus ilex L. Canadian Journal of Botany. (Revue Canadienne De Botanique) 82, 1711-1729.

Richard, F., Millot, S., Gardes, M., Selosse, M.A., 2005. Diversity and specificity of ectomycorrhizal fungi retrieved from an old-growth Mediterranean forest dominated by Quercus ilex. New Phytologist 166, 1011-1023.

Riviere, T., Diedhiou, A., Diabate, M., Senthilarasu, G., Natarajan, K., Verbeken, A., Buyck, B., Dreyfus, B., Bena, G., Ba, A., 2007. Genetic diversity of ectomycorrhizal Basidiomycetes from African and Indian tropical rain forests. Mycorrhiza 17, 415-428.

Rosling, A., Lindahl, B.D., Taylor, A.F.S., Finlay, R.D., 2004. Mycelial growth and substrate acidification of ectomycorrhizal fungi in response to different minerals. FEMS Microbiology Ecology 47, 31-37.

Schutzendubel, A., Polle, A., 2002. Plant responses to abiotic stresses: heavy metalinduced oxidative stress and protection by mycorrhization. J. Exp. Bot 53, 1351-1365.

Shipley, B., 2000. Cause and Correlation in Biology: a User's Guide to Path Analysis, Structural Equations and Causal Inference. University Press, Cambridge.

Smith, M.E., Douhan, G.W., Rizzo, D.M., 2007. Ectomycorrhizal community structure in a xeric Ouercus woodland based on rDNA sequence analysis of sporocarps and pooled roots. New Phytologist 174, 847-863.

Smith, S.E., Read, D.J., 1997. Mycorrhizal Symbiosis Academic Press, San Diego, 605 pp.

Soil Survey Staff, 2006. Keys to Soil Taxonomy, 10th ed. USDA-Natural Resources Conservation Service, Washington, DC.

Taylor, A.F.S., Alexander, I.A.N., 2005. The ectomycorrhizal symbiosis: life in the real world. Mycologist 19, 102-112.

Tedersoo, L., Jairus, T., Horton, B.M., Abarenkov, K., Suvi, T., Saar, I., Kõljalg, U., 2008. Strong host preference of ectomycorrhizal fungi in a Tasmanian wet sclerophyl forest as revealed by DNA barcoding and taxon-specific primers. New Phytologist 180, 479-490.

ter Braak, C.J.F., Smilauer, P., 2002. CANOCO Reference Manual and CanoDraw for Windows User's Guide: Software for Canonical Community Ordination (version 4.5). Microcomputer Power, Ithaca, NY, USA, 500 pp.

Urbieta, I., Zavala, M., Marañón, T., 2008. Human and non-human determinants of forest composition in southern Spain: evidence of shifts toward cork oak dominance due to management over the past century. Journal of Biogeography $35,1688-1700$.

Walker, J.F., Miller, O.K., Horton, J.L., 2005. Hyperdiversity of ectomycorrhizal fungus assemblages on oak seedlings in mixed forests in the southern Appalachian Mountains. Molecular Ecology 14, 829-838.

Warwick, R.M., Clarke, K.R., 1995. New biodiversity' measures reveal a decrease in taxonomic distinctness with increasing stress. Marine Ecology Progress Series 129, 301-305

Weiher, E., Keddy, P.A., 1995. The assembly of experimental wetland plant communities. Oikos 73, 323-335.

White, T.J., Bruns, T., Lee, S., Taylor, J.W., 1990. Amplification and direct sequencing of fungal ribosomal RNA genes for phylogenetics. In: Innis, M.A., Gelfand, D.H., Sninsky, J.J., White, T.J. (Eds.), PCR Protocols: A Guide to Methods and Applications. Academic Press, New York, pp. 315-322.

Zinke, P.J., 1962. Pattern of influence of individual forest trees on soil properties. Ecology 43, 130 